\title{
Protection of Environment in Serbia: Responsibility for Ecological Economy Offences
}

\author{
Miodrag N. Simović \\ Constitutional Court of Bosnia and Herzegovina, Sarajevo, Bosnia and Herzegovina \\ University of Banja Luka, Banja Luka, Bosnia and Herzegovina \\ Academy of Sciences and Arts of Bosnia and Herzegovina, Sarajevo, Bosnia and Herzegovina \\ Russian Academy of Natural Sciences, Moscow, Russia \\ European Academy of Sciences and Arts, Salzburg, Austria \\ Dragan Jovašević \\ University of Niš, Niš, Republic of Serbia \\ Vladimir M. Simović \\ Prosecutor's Office, Sarajevo, Bosnia and Herzegovina \\ Independent University, Banja Luka, Bosnia and Herzegovina \\ “Apeiron” University, Banja Luka, Bosnia and Herzegovina
}

\begin{abstract}
A new system of protection, regulation, and improvement of environment has been introduced in Serbia since 2004, on the basis of numerous fatified universal and regional international documents. Preventive measures having the aim to prevent the possibility of jeopardizing, endangering, or pollution of the environment as a whole or some of its segments like air, water, soil, flora, and fauna have a special importance in the system of ecological protection of biodiversity. However, in case when such preventive measures are not sufficient or efficient, ecological values are protected from different forms of violation and jeopardizing by prescribing ecological delicts like: criminal offences, economic felonies and offences. These delicts having wide range of measures, sanctions, and actions lead by competent courts (general, economic, or misdemeanor) for natural and legal persons, i.e. enterpreneurs, should provide efficient, quality, and legal ecological security, that is its protection from economic offences and that is what this paper is about.
\end{abstract}

Keywords: environment, regulation, protection, economic offence, sanction

\section{Forms of Violation and Endangering of Environment}

Miodrag N. Simović, judge of the Constitutional Court of Bosnia and Herzegovina, Sarajevo; full professor, Faculty of Law, University of Banja Luka, Banja Luka; corresponding member of the Academy of Sciences and Arts of Bosnia and Herzegovina, Sarajevo, Bosnia and Herzegovina; foreign member of the Russian Academy of Natural Sciences, Moscow, Russia; active member of the European Academy of Sciences and Arts, Salzburg, Austria.

Dragan Jovašević, full professor, Faculty of Law, University of Niš, Niš, Republic of Serbia.

Vladimir M. Simović, prosecutor, the Prosecutor's Office of Bosnia and Herzegovina, Sarajevo; associate professor, Faculty of Security and Protection of Independent University, Banja Luka and Faculty of Law, "Apeiron” University, Banja Luka, Bosnia and Herzegovina.

Correspondence concerning this article should be addressed to Miodrag N. Simović, R.Dž.Čauševića 6/III, Sarajevo 71000, Bosnia and Herzegovina. 
Technical and technological development and use of huge sources of energy and raw materials in 20th century and beginning of the third millenium resulted in human work being greatly replaced or complemented by machines, appliances, and other gadgets made of metal, plastic and other materials of different drives and energy sources, which, to be honest, made living more easier and enriched and more beautiful, but also endangered it at different levels, at the same time (Simović, 1988, pp. 19-27). Huge number of machines which are automatized and computerized, use of various, even dangerous, sources of energy, and raw materials have enormous manufacture power, but, on the other hand, a power of destruction or endangering of life and health of humans, is jeopardizing human life and work environment and, thereby, basis of his existence, life and survival (Jovašević, 2009, pp. 35-49).

Use of nuclear, thermonuclear, electrical, sun and other sources of energy enabled a man to overcome vast space on Earth and made them available in a short period of time, to go into the depth of the Earth or vast space or ocean space, going deeper and deeper into secrets of life and nature, secret mysteries and a man itself. So a man discovered and mastered these forces, created such means, and found such technological procedures by which he became a master of nature and his destiny to a great extent. But, these forces result in dangers of uncontolled, unprofessional, unintentional, accidental, or other inconsiderate acts and spreading, and, at the same time, of destruction and damagining of everything on its way, causing imminent danger to the environment, i.e. life and health of people (Jovašević, 2014, pp. 178-181).

Destructive power of energy, raw materials and means are used in all forms of manufacture and reseach is not only permanently present and possible at all times, but is also realistically achievable. This, however, shows us a number of examples from closer and far distant past in the light of numerous industrial, chemical, oil and other accidents, which has led to an ecological catastrophe of immeasurable proportions. Fires, floods, explosions, damages, poisoning, accidents of various kinds (Aleksić, 1986, pp. 42-48), scale and duration, are frequent occurrences in which we often have severe or even catastrophic environmental consequences with a large number of human casualties and body harms, endangering or injuring the health, and the enormous material damage of air, water, soil, flora, fauna, and other segments that together form the ecological environment (Jovašević \& Ikanović, 2012, pp. 213-216). This is another, dark side and the tribute consequence of technical and technological progress during the last half century (Ljuština, 2005, pp. 713-724).

\section{Protection of Environment}

Environment understands natural and work-created values, as well as the total space in which a man lives and where settlements are located, goods in general use, industrial and other objects. This means that the environment, which is the subject of organization, management, protection, and preservation as part of ecological law, consists of two groups of values (Joldžić, 2007, pp. 45-61). These are: a) the natural values of the environment which are: natural resources, land, water, forests, air, flora, and fauna; and b) work created values of the environment that make man-made creations that serve for the satisfaction of general, common, and individual human needs and are intended for housing, cultural, educational, social, religious, and other needs of a man.

Thus, the following is cosidered as environmental factors: land, water, air, flora, and fauna that are contained in lithosphere, pedosphere, hydrosphere, atmosphere, biosphere, and technosphere. Due to its special importance for society, its survival, as well as future development, the system of protection and improvement of the environment is defined as a set of measures and requirements for: preservation and protection of natural 
and work created values of the environment; protection of the people and the environment from pollution; protection against the effects of harmful and dangerous substances, ionizing and non-ionizing radiation, noise and vibrations; protection against destruction and degradation of natural values, as well as measures and requirements for improvement of the quality of the environment. Today, system of protection and improvement of the environment (Matijević, 1988, pp. 40-45) consists of more than one hundred regulations on: planning and design of space and settlements, construction of building, mining, geological explorations, protection of waters, soil, flora and fauna, forests, national parks, waste management, traffic of poisons, traffic and transport of explosive and dangerous materials etc. Such system, defined with a huge number of provisions and authorizations divided into different sectors of different state organs, public services or public companies, could not achieve protection of environment in a harmonized and consistent manner.

Economic and non-economic interests and reasons dictated the conditions and the way of exploitation of natural resources and goods, without taking into account direct or indirect environmental impacts. The current approach has had, at the republic and other levels, uneven plans and decisions, the absence of coordination and action of all the subjects in the protection and preservation of natural resources, goods and environment on the territory of the Republic of Serbia. A large number of laws and other regulations do not have a single set of goals and do not provide satisfactory effects in terms of responsibile and solidary relation towards the use of natural values and the protection of environment. A seemingly well-designed system of environmental protection lacks a consistent approach in making and enforcing decisions, as well as a harmonized system of requirements and measures of prevention and control of the use of natural resources and goods, or the protection of the environment (Jovašević \& Milošević, 2002, pp. 205-209).

As to environmental protection problem many countries face the need to eliminate inherited pollution and, at the same time, they take preventive measures and control sources of new pollution (Jovašević, 2001a, pp. 139-152). Although all industrial countries have gone through or are going through this phase, many of them are starting to deal with problems by applying new approaches. Integrated approaches of managing with individual resources are being developed, such as water or an integral approach to managing all natural resources ${ }^{1}$. Reducing impacts to environment by promoting and introducing waste recycling becomes a central issue in the policy of environmental protection of many countries. Countries such as Germany, Switzerland, Denmark, etc., already have or are developing programs of clean technologies aimed at avoiding and reducing waste and industrial wastewater. These efforts, though often initiated by regulations, are inspired by industry groups and from interested citizen associations (Jovašević, 2011, pp. 389-391).

European Union strives towards standardization of criteria with requirements regarding preservation and increasing of environmental quality. Especially important fact is that in Europe economic and ecological aims are integrated, and measures of preventive actions are emphasized. It is this integration that may become basis for consensus of developments goals in Europe (Jovašević, 2002, pp. 201-204). It is therefore necessary for the Republic of Serbia to have an efficient environmental protection system, especially for new investment projects and participation of foreign capital. In the forthcoming period, the first changes in the structure of economic activity in ecologically and economically endagered areas can be expected. The protection of the environment must be realized as a clear and practical framework that does not fetter development, but supports and stimulates it (Mecanović, 1986, pp. 257-269). Adapting of these requirements implies a fast and efficient

\footnotetext{
${ }^{1}$ Obrazloženje nacrta Zakona o sistemu zaštite životne sredine, Vlada Republike Srbije, Beograd, 2002.
} 
implementation of measures and activities that would enable the Republic to be equally involved in these processes. Such orientation requires not only international cooperation, but also international assistance (Joldžić, 2007, pp. 61-71).

Starting from the constitutional orientation and the fact that the environmental problems justify the intervention of the Republic in order to protect the human and citizens' rights and that they are an inseparable part of their overall development, the concept of a system of environmental protection has been established, and it is based on: 1) making and enforcing decisions that ensure the balance between environmental protection and economic development through the integration of environmental protection into all sectoral policies; 2) planning and rational use of natural resources, goods, and energy; 3) application of regulations through licensing system, technical and other standards and norms, provision of financing, incentive and other measures of environmental protection; 4) preserving and raising of the quality of the environment; 5) monitoring, preventing, and limiting adverse impacts on the environment; 6) introducing of energetically more economic technologies and gradual transfer to use of renewable natural resources; 7) integration of economic analysis and ecological assessments when assessing projects profitability with the aim of including expenses for negative effects on the environment; 8) encouraging of production and use of products and the application of technologies that reduce environmental pollution and waste generation; 9) protection of particularly valuable, endangered, or damaged areas; 10) repair of damage caused to the environment; 11) reduction, re-use, and recycling of waste; 12) improving education, training of staff, and developing the awareness of the importance of environmental protection; and 13) participation of public in environmental protection.

Given the danger of various forms of damagining or endangering the environment, the international community has, as we have already seen, taken a number of measures to establish a unique basis for the establishment of "sustainable development of the environment". Namely, the policy of sustainable development represents a new social relation towards the environment, space, and natural resources, with the full awareness of existence of responsibility before future generations. The rational relation towards the exploitation of the available natural resources is an imperative for civilization existence ${ }^{2}$. This sustainable development is achieved by adjusting the structure and dynamics of human activities to the structure and dynamics of the environment. It implies structural, technical, and technological changes so as to ensure the further degradation of the environment is stopped (Čejović, 1985, pp. 147-161).

In the past few years, efforts have been made in the Republic of Serbia to build an adequate, professional, efficient programme for maintenance, development, improvement, and protection of the environment (Jovašević \& Milošević, 2001, pp. 1-16). There are a number of laws and bylaws of different legal force and importance in the Republic of Serbia that in various ways address the issues of environmental protection in their entirety or in some aspects such as food, water, air, soil etc. (Gozze, 1980, pp. 7-87). Doing this would be an attempt to create a solid legal basis of legal and subordinate character that would create obligations of all the subjects in social life when acting in their everyday life and work, i.e. the basis of responsibility and punishment in case of violation of these regulations.

\section{System of Ecological Delicts}

The vast majority of these activities of men that hurt, destroy, damage, pollute, or endanger the

\footnotetext{
${ }^{2}$ Napori Ujedinjenih nacija za bolju životnu sredinu, Savezno ministarstvo za razvoj, nauku i životnu sredinu, Beograd, 1997, pp.
} $1-2$. 
environment are the result of the conscious omissions or non-application of rules, technical guidelines, and standards in dealing with a number of dangerous sources of energy and raw materials, i.e. in handling or otherwise dealing with dangerous devices. This creates the conditions for the risk of accidents of various kinds, forms, and dimensions, covering a certain space and all that is found in it, in the zone of danger caused this way (Jovašević, 1999, pp. 49-65).

Such activities of individuals and groups, and even of entire states (especially multinational companies), represent illegal, prohibited, and punishable or delinquent behaviors or delicts (Andrić, 1982, pp. 17-29). Since these are illegal behaviors in the area of planning, preservation, improvement, and protection of man's living and working environment in a wider or closer environment, all these types of delictes can be called ecological delicts (ecology: greek oikos — house, habitat and logos—science). Depending on the extent and intensity of the effects on the environment, the activities undertaken, the characteristics of the perpetrator of the delict, and the concrete behavior prescribed under the laws and other by-laws of the general nature and the types of prescribed sanctions, we may differ from different types of ecological delicts (Jovašević, 2003, pp. 60-71).

Ecological crimes (Grgurević, 1999, pp. 67-76), therefore imply the totality of human behaviors violating or endangering social values that determine the conditions for preservation, improvement, and protection of the living and working environment of a man (Jovašević, 2016, pp. 178-181). They are only a type or part of the total delinquency with which one society - the state faces in a given period of time, i.e. humanity as a whole (Čejović, 1976, pp. 251-263). These delinquent behaviors are different from other types of delicts just by the object of protection (a set of social values which are violated or endangered by these activities, which in this case represents - a man's healthy environment (Arsenovski, 1979, pp. 485-498), on the one hand, or the right of a man - as one of the basic human rights to healthy living conditions, on the other hand).

This object of protection is also the result of taking the action of execution. It manifests in a twofold way. Firstly, this may be the consequence of injury (destruction, damage to a greater or lesser extent, or making living and working environment of a man unusable) and, secondly, the consequence of endangering (which may be concrete, immediate, real danger, or abstract danger). Mostly, this consequence is a result of the activity of commission (active, positive activity) or non-commission (negative, passive activity), by violating the regulations on the protection, preservation, or improvement of the environment or by violating other regulations on handling with gadgets, appliances, raw materials, energies or other sources of general danger for the life or the body of humans and their property. However, the structure of ecological delictes (Jovašević, 2002a, pp. 53-59), regardless of the number of common characteristics they have, can be clearly classified in three types of delictes. These are: 1) criminal offences; 2) economic offences; and 3) petty offences (Čejović, 1978, pp. 353-361).

The first group of these delicts is the most dangerous illegal behavior of natural persons for which the most severe types of criminal sanctions are prescribed by law. These are criminal offenses (Jovašević \& Ikanović, 2012, pp. 312-314). These delicts are called ecological criminality. Within this kind of delicts, two types of ecological crimes differ again (Petrović, Jovašević, \& Ferhatović, 2016, pp. 312-319).

These are: 1) real ecological criminal offenses (or ecological criminal offenses in the narrow sense) that are systematized in the Criminal Code in a group of criminal offenses against the environment. As direct object of protection they have the environment itself as a whole or some of its segments that make a healthy and natural human environment; and 2) improper ecological criminal offences (or ecological criminal offenses in the broader sense) that are systematized in the Criminal Code, in other groups of criminal offenses (Ignjatović, 
1998, pp. 203-211). They are, indirectly, directed against the environment, but besides it as a predominant or prevalent object of protection, some other social values are emerging in relation to these acts (hence depending on these criteria these acts are systematized into appropriate groups of criminal offenses).

Economic offences and violations are violations of norms of legal order for which offense or misdemeanor sanctions (penalties or protective measures) are prescribed under the law or bylaw provisions. These are the delicts of lower degree and intensity of social danger, if at all it is assumed that social danger appears as an integral part or an element of their notion (which, however, is a lonely opinion in criminal law literature). Economic offences and petty offenses fall into the sphere of ecological delinquency in the broader sense-along with criminal offences (ecological crime).

\section{Relationship Between Individual Types of Ecological Delicts}

As we have already seen, in the system of criminal law of the Republic of Serbia, there are three types of punishable, illegal, and unallowed behaviors. These are: 1) criminal offences; 2) economic offences; and 3) petty offences. Protection of the most significant social goods and values for such determined punishable beharious should be provided in an efficient, quality, and timely manner. But, before we go to the presentation of the term and characteristics of individual types of ecological delicts in accordance with existing crimnal legislation (criminal, economic offences, and petty offences) in the Republic of Serbia (Čejović, 1982, pp. 187-196), it is necessary to draw the attention to basic differencies and similarities (relationship) between individual types of delicts given the characteristics, features, structure and significance (Todorović \& Jovašević, 2003, pp. 245-250).

\section{Relationship Between Criminal Offences and Economic Offences}

The criminal offense is an unlawful, committed offense whose features are defined in the law. Thus, the first basic difference between criminal offenses and economic offenses derives from the above definition. Economic offences are socially damaging violations of the regulations on economic and financial affairs (Jovašević, 2002b, pp. 12-43).

In literature, one can find such a standing that economic offences are offences of lesser or weaker intensity and quantum of social danger than the criminal offenses are. The basis of this standing is, among other things, also in the definition of the concept of economic offense under the 1977 legal text when the element of social harm in general was not even entered into the legal description of the characteristic of an economic offense (Jovašević, 2001c, pp. 67-72). By this way, economic offences were considered to be less socially dangerous offences that are among criminal offenses (as the most dangerous behaviors) and petty offences (as violations of legal regulations and social discipline in the widest sense) on the scale of punishable acts.

But this standing on the degree of economic offenses and criminal offenses, by the degree and intensity of social danger - can not withstand a serious criticism. This is particularly the case if having in mind that economic offences are primarily the delicts of the legal person (whose responsibility is primary), and only then the delicts of the responsible person in the first person. As such, economic offences, in concrete life situations, can not only be socially lighter offences in terms of the intensity of danger, but can also be significantly more serious and more dangerous offences that cause greater harm to the interests of the community as a whole (Jugović, 1990, pp. 41-49). This is even more because in the case of commission of economic offense by a legal person, responsible person in that legal person may also be accountable for a criminal offense (in which 
case he is not penalized for the economic offense at all) if the characteristics of an economic offense are identical to those of a criminal offense (therefore, when there is an objective identity of the factual description of the criminal offense and economic offense).

In such situations, it is indisputable that economic offense appears as a kind of criminal offense, but with a specific perpetrator - a legal person. It is this specificity of the perpetrator of a concrete act, such as forbidden and punishable behavior, which is the reason to define it as an economic offense rather than a criminal offense. The legislator therefore sets parallel and simultaneous liability of the legal person and its responsible person for the economic offense committed, bearing in mind the aim and purpose of punishing of the legal person as a set of all individuals, a group of employees who are a part of it and that all of them have achieved the features of an economic offense.

The social risk of economic offences, as a delicts of responsible persons, lies at the level of criminal offenses in cases where committed economic offences completely coincide with criminal offenses, in which case a responsible person of a legal person himself is not responsible for economic offence but for a criminal offence. However, there are such cases when a new economic offense, according to its severity and social harm or danger, corresponds to the criminal offense, but is not yet prescribed as such, but only its economic and offence responsibility and punishability of the perpetrator are prescribed by a decree. And in that case, the accused reponsible person is responsible for the economic offense, but only until such a behavior is determined by law as a criminal offense (Jovanović, 1976, pp. 81-89).

The next difference between the criminal offense and the economic offense is reflected in the object of protection. Namely, the protective objects in economic offenses are certain economic and financial relations, i.e. the economic system as a whole. These relations are governed by an economic system that fully provides the maintenance and development of the ruling social relations in the sphere of economy and business in general. Accordingly, the protective object in economic offences is the economic and financial system and its undisturbed, legitimate, efficient, and timely functioning. Contrary to that, in the case of criminal offenses, the object of protection is defined as a man (citizen) and a society (state). This means that the object of protection in economic offenses is much narrower than it is the case with criminal offenses.

A criminal offense can only be committed by a natural person (who, at the time of the commission of the offense, was 14 years old and who, with guilt — and thus culpability, committed a criminal offense). Different subjects can be perpetrators of an economic offense. These are: a legal person (company, institution or other organization), responsible person, and entrepreneur. This element reflects the next distinction between criminal offenses and economic offenses. Natural person in criminal and legal sense is always and only responsible under the principle of subjective responsibility.

In the case of economic responsibility, there are two, simultaneous and parallel responsibilities-of legal entity and its responsible person (Jovašević, 2000a, pp. 33-40). Of course, the legal entity is primarily responsible, based on the principle of objective responsibility on the basis of the very cause of the consequence. The responsible person and the entrepreneur respond in accordance with the principle of subjective responsibility on the basis of which the fault lies. With regard to the foreseen action in the law, or in the regulation (principle of lawfulness or legality), there is the following distinction between criminal offenses and economic offenses. Namely, criminal offences and sanctions for their perpetrators can only be foreseen by a law only (criminal or subsidiary laws). On the contrary, economic offences, their features and sanctions can be determined not only by laws, but by regulations of subordinate character (government decrees). This solution is 
actually a consequence of the necessity for speed of development and expansion of economic relations and the need for a fast and frequent change of provisions and regulations in line with changes in social relations and more different ways of violation of regulations in the field of economic and financial affairs. It is the regulations as the highest level bylaws that can be passed in a fast and efficient way that can be harmonized with new social and economic relations (Kosanović, 1995, pp. 333-341).

The system of sanctions for certain types of punishable offenses represents the following distinction. For criminal offenses, the law envisaged a wide range of punishments (imprisonment, fine, work in the public interest and driving license revocation) and other types of criminal sanctions such as: safety measures, educational measures, and warning measures (conditional sentence and judicial warning). However, for economic offences there are far fewer sanctions available to society when choosing the most effective means to combat this kind of economic delinquency. Only one kind of punishment (fine), conditional sentences, and protective measures (which, by their nature, content, and purpose, are equivalent to the security measures) may be imposed for economic offences. In both cases, the type and the amount of prescribed punishment as the sole expression of the legislator's assessment of the degree of severity and danger (or social harm) of a particular behavior, given that the punishment imposed should be proportional to the gravity of the offense and degree of danger of the perpetrator in both cases, which means that the competent court in each individual offense committed determines the sentence according to the danger of the committed offense and personality of the perpetrator.

Finally, the last but not the least difference between criminal offenses and economic offenses is reflected in the competencies of bodies involved in the proceedings following the commission of the punishable offense. Therefore, for criminal offenses the proceedings are conducted upon the request of a public prosecutor before a court of general jurisdiction (municipal or district court), while the proceedings for economic offences are also conducted upon the request of the competent public prosecutor, but before the commercial court (Prodanović, 1988, pp. 32-43). However, it should be emphasized that the relevant provisions of the Code of Criminal Procedure, i.e. the Criminal Sanction Act, should accordingly be applied in the procedure for economic offences (regardless of whether these are procedural or executive provisions).

\section{Relationship Between Criminal Offences and Offences}

With regard to the distinction between the criminal offense and offense (Jovašević, 2012, pp. 45-49), as different punishable acts, theories of criminal law developed two theories: qualitative and quantitative. According to qualitative theory, offenses and criminal offenses differ in their essence, even though they represent public law delicts. The criminal offense violates the legal norm, legal good, or legal interest, while such violation does not constitute a conceptual definition of the content of the offense. This means that criminal offenses violate or endanger goods of great social value, while this is not the case with offenses. According to quantitative theory, the difference between a criminal offense and an offence is not essential, but consists of a different quantum (quantity) of danger or harm of the action taken by the perpetrator in the execution of a particular offense. Namely, a criminal offense is an unlawful act that violates or endangers protected goods and values in a society. On the contrary, the offense in general has no element of social danger, but the social harm of such a delict is expressed to a much lesser extent. Of course, this social harm, i.e. its quantum, is determined on the basis of two criteria: the importance of a legal asset attacked by such a delict and the type, extent, and intensity of the resulting consequence, or other objective and subjective circumstances that followed the 
execution of the offense.

The criminal offense is unlawfully committed offense established as a criminal offense by law (Vrhovšek, 2007, pp. 15-20). Offences are socially harmful violations of the public order provided for in regulations for which punishments and protective measures are prescribed. With regard to the general elements of the concept of criminal offense and the offense, it must be emphasized that there are no elements of social danger and the determination of acts in law (the principle of legality) on the side of an offense. Offences can be determined not only by a law, but also by bylaws (by decision of the Assembly of the Autonomous Province, the Assembly of the City or the Municipality Assembly). Regarding the subjects of these delicts, only a natural person may appear as a perpetrator of the criminal offense, whereas fulfillment of conditions for the existence of subjective responsibility is required for his responsibility (Lutenberger, 2007, pp. 79-89). The offences have three types of subjects. In addition to the natural person and the entrepreneur who are accountable on the principle of subjective responsibility, as perpetrators of an offence, a legal person (who is responsible on the basis of causing consequences, i.e. upon the principle of objective responsibility), and a responsible person in the legal person (who is also responsible on the basis of subjective responsibility) may also appear.

Regarding the sanctions for criminal offenses, the above-mentioned types of criminal sanctions are prescribed, while the following sanctions may be imposed to the offenders: punishment (imprisonment and fine), reprimand, warning, protective measures (corresponding to the purpose, character, and content of the security measures) and educational measures. Execution of both criminal and petty offence sanctions is carried out in the same correctional institutions, according to the same procedure, based on the same educational methods and treatments of re-socialization, and all of it in accordance with the provisions of the Law on Execution of Criminal Sanctions of the Republic of Serbia. The procedure for determining of liability for criminal offenses shall be initiated ex officio by a special state organ, a public prosecutor, and shall be conducted before a regular court (municipal and district). The petty offence procedure is initiated upon the request of an authorized organ, and is conduced by a special Petty Offence Court (Milenković, 1998, pp. 67-70).

If a punishable behavior is simultaneously foreseen as a criminal offence and as a petty offence, in that case the criminal offense, as more difficult and more dangerous one, absorbs the offense. The circumstance that one person is punished for a criminal offense is a ground that excludes liability and punishability for an offence, provided that the factual background of both punishable offenses meets the conditions of identity.

\section{Ecological Economy Offences}

A new ecological legislation (Krivokapić, 1990, pp. 43-49), in addition to the regulations relating to various aspects of editing, maintaining, improving, and protection of the environment (in particular with regard to the preventive measures, actions, and procedures with the aim to prevent and forestall violation or endangering of environment in its entirety or some of its segments), in the end, usually contains penal provisions. In fact, in this way, the responsibility for ecological economy offences is prescribed (Arnaudovski, 1983, pp. 397-405). Thus, the system of economic offenses in the environmental penal legislation of the Republic of Serbia is today determined by the following laws: 1) Environmental Protection Law; 2) Law on Integrated Pollution Prevention and Control of Environmental Pollution; and 3) Environmental Impact Assessment Law (Aksentijević, 1981, pp. 56-84).

\section{Economy Offences From the Environmental Protection Law}


The first law in the field of environmental law that foresees responsibility for economic offences is the Environmental Protection Law. Article 116 of this Law prescribes the responsibility of a legal person (company, institution, or other organization) and its responsible person for a committed economic offense that violates the provisions of this Law. For this delinquent behavior, the following sanctions are prescribed: 1) for a legal entity - $\mathrm{a}$ fine of between 150,000 and 300,000 dinars; and 2) for a responsible person in the legal entity - a fine of between 30,000 and 200,000 dinars.

This economic offense exists in the following cases if the offender: 1) uses natural resources and goods without the consent of the competent administration organ - the ministry; 2) in the use of resources and goods, during the execution of the works and upon their termination, does not take measures to rehabilitate endagering of the environment; 3) do not recultivate or otherwise rehabilitate the de-graded environment; 4) collects and puts into circulation certain species of wild flora and fauna, their development forms and parts without the permission of the competent ministry, or contrary to the requirements laid down in the permit; 5) imports and exports endangered and protected species of wild flora and fauna, their development forms and parts without the permission of the ministry, or contrary to the established requirements; 6) does not undertake any necessary protective and safety measures in the management with hazardous substances; 7) does not make an assessment of the risk of injury; 8) builds and uses plants and perform activities if the emission and exhaust emission standards, equipment, and devices, which reduce or prevent emission of pollutants or energy, are not met and if no other measures and actions have been taken to secure the prescribed requirements for environmental protection; 9) releases polluting and dangerous substances, waste water or emits energy in the air, water or soil in the manner and in the quantities or concentrations or levels above prescribed; 10) produces and places into market means of transportation that do not meet the requirements with regard to emission of mobile sources of pollution; 11) applies domestic or imported technology or process, i.e. producest and pleces into market products that do not meet the prescribed standards of environmental protection, i.e. the standards of quality of products or the technology, process, product, semi-finished product, or raw material is banned in the exporting country; 12) uses devices used for the removal or purification of polluting substances for which domestic standards are not prescribed contrary to the provisions of this Law; 13) the declaration of raw material, semi-product, or product does not warn of environmental pollution and damage to human health that raw material, semi-product, or product, or its packaging causes, or may cause to the environment; 14) produces substances that damage the ozone layer; 15) imports and exports substances that damage the ozone, i.e. products containing these substances, which have been established under ratified international agreement, from countries or into countries that are not contracting parties to this agreement; 16) imports, manufactures, and puts into market new and used products containing substances that damage the ozone layer contrary to the provisions of this Law; 17) imports and exports substances that damage the ozone layer without the permission of the Ministry; 18) imports hazardous waste; 19) imports, exports, or carries out waste transit without the permit of the Ministry and set requirements; 20) does not act in accordance with the provisions of this Law; 21) does not take sanation measures at its expense; 22) does not make or does not realize the sanation plan; and 23) does not secure itself from the case of damage caused to third parties due to the incident.

\section{Economic Offence From the Law on Integrated Prevention and Control of Environmental Polution}

The Second Ecological Law, passed in 2004, which provides for economic offence responsibility of a legal person and its responsible person for violating or endangering of the environment by violating the 
provisions of that Law - is the Law on Integrated Prevention and Control of Environmental Pollution. Article 29 of this Law foresees an economic offense that exists if the offender commits any of the following alternative activities, and if he/she: 1) starts the operation of the plant and performs its activities without a prescribed permit; 2) does not act in accordance with the conditions set out in the issued permit; 3) does not submit to the competent authority the results of the monitoring; 4) does not notify the competent authority of any change in work, i.e. the functioning of the plant or of the icident; 5) does not submit to the competent authority an annual report on the activities for which the permit was issued; 6) does not notify the competent authority about the planned change of operator; 7) fails to carry out all measures established by the competent authority after the termination of the validity of the permit; and 8) does not correct the consequences of the pollution as soon as possible and at its expense.

Different punishment is prescribed for the economic offense committed, depending on the capacity of the perpetrator of this delict. Thus, a domestic legal entity - operator is punished by a fine ranging from 150,000 to 3,000,000 dinars. Foreign legal entity - operator is also punished for the same offence, with the same fine, but only under the condition if it has a branch office within the territory of the Republic of Serbia. And finally, a responsible person in a domestic or foreign legal entity_operator will be punished for a committed offense with a fine of between 30,000 and 200,000 dinars.

\section{Economic Offences From the Law on Environmental Impact Assesment}

The latest 2004 environmental law, which knows the responsibility for economic offences, is the Environmental Impact Assessment Law. This Law in Article 40 provides for an economic offense committed by a legal person - the project holder or its responsible person if: 1) starts with realization of the project without the consent of the competent authority to the impact assessment study; 2) does not fulfill the requirements or does not take measures from the decision granting consent to the impact assessment study; and 3) does not obtain the consent of the competent authority to the current condition study.

For this economic offence, a fine in the amount of 150,000 to 3,000,000 dinars is prescribed for a legal entity - as a project holder. A responsible person in the legal entity - the holder of the project, shall also be sentenced with a fine in the amount of 30,000 to 200,000 dinars. However, in addition to the sentence, a legal person as a perpetrator of this offense, according to the law, may also be pronounced a protective measure-a measure prohibiting to perform a particular activity, or protective measure to its responsible person-a measure prohibiting the exercise of a particular duty for a period of up to five years.

\section{Conclusion}

For the purpose of efficient, quality, timely, and legitimate environmental protection, in its entirety or in some of its elements: air, water, land, flora, and fauna, all modern legislations, including the new legislation of the Republic of Serbia, starting from 2004, proved for a wide range of different measures, means, and procedures, as well as authorities of the competent state and other social organs and organizations. However, when this preventive measures system does not show results and does not produce effects, liability is prescribed for natural and legal persons who, by their unlawful behavior, violate, or endanger the environment. Imposing and enforcement of sanctions for perpetrators of ecological delicts follow as a consequence of this liability, and it appears in three forms. Economic offences constitute a specific and a very numerous kind of ecological delicts for which theory and practice have not shown enough consideration and interest to date. 


\section{References}

Aleksić, Ž. (1998). Krivična odgovornost za nehatne i namjerne požare. Beograd: Bezbjednost i društvea samozaštita, (4).

Aksentijević, S. (1981). Privredni prestupi u zakonodavstvu i praksi. Beograd.

Andrić, M. (1982). Privredni prestupi, prekršaji i krivična djela. Beograd.

Arnaudovski, L. J. (1983). Krivična djela i privredni prestupi u saveznom, republičkom i pokrajinskom zakonodavstvu. Beograd:

Jugoslovenska revija za kriminologiju i krivično pravo, (3-4).

Arsenovski, M. (1979). Krivičnopravnata zaštita na čovjekovata okolina. Skoplje: Bezbjednost, (5).

Čejović, B. (1976). Neki aspekti zaštite životne sredine. Priština: Obilježja, (2).

Čejović, B. (1978). Krivičnopravna zaštita čovjekove životne sredine. Zagreb: Zbornik Pravnog fakulteta u Zagrebu, (3-4).

Čejović, B. (1982). Krivična djela protiv čovjekove okoline. Beograd: Pravni život, (2).

Čejović, B. (1985). Krivično djelo izazivanja opšte opasnosti požarom. Beograd: Jugoslovenska revija za kriminologiju i krivično pravo, (4).

Gozze Gučetić, V. (1980). Krivična zaštita čovjekove prirodne sredine u SFRJ. Beograd: Jugoslovenska revija za kriminologiju i krivično pravo, Beograd, (1).

Grgurević, S. (1999). Ekološka stajališta promjena u kaznenom zakonodavstvu. Zagreb: Socijalna ekologija, (1-2).

Ignjatović, A. (1998). Ugrožavanje života ljudi izazivanjem opšte opasnosti. Beograd: Pravni život, Beograd, (9).

Joldžić, V. (2007). Krivična, disciplinska i materijalna odgovornost za zagađivanje životne sredine, kaznena politika u oblasti zaštite u svijetu i kod nas. Beograd.

Jovanović, L. J. (1976). Krivičnopravna zaštita životne sredine. Zbornik radova "Zaštita čovjekove sredine”, Niš.

Jovašević, D. (1999). Krivično djelo izazivanja opšte opasnosti-teorijski i praktični aspekt. Beograd: Jugoslovenska revija za kriminologiju i krivično pravo, (3).

Jovašević, D. (2000a). Karakteristike odgovornosti za privredne prestupe u našem pravu. Novi Sad: Pravo, teorija i praksa, (9-10).

Jovašević, D. (2000b). Zbirka zakona o prekršajima sa komentarom i praksom. Beograd.

Jovašević, D. (2001a). Zaštita životne sredine u uporednom krivičnom zakonodavstvu. Zbornik Fakulteta civilne odbrane, Beograd.

Jovašević, D. (2001b). Privredni prestupi u sudskoj praksi-Praktikum. Beograd.

Jovašević, D. (2001c). Komentar Zakona o privrednim prestupima sa sudskom praksom. Beograd.

Jovašević, D. (2002a). Krivičnopravna zaštita životne sredine. Beograd: Sudska praksa, (2-3).

Jovašević, D. (2002b). Komentar Krivičnog zakona SRJ. Beograd.

Jovašević, D. (2002c). Odgovornost za ugrožavanje životne sredine po evropskim konvencijama. Zbornik radova "Sistemska analiza šteta u privredi, osiguranju i preventivno inženjerstvo", Beograd.

Jovašević, D. (2003). Sistem ekoloških krivičnih djela u našem pravnom sistemu. Beograd: Sudska praksa, (11-12).

Jovašević, D. (2009). Sistem ekoloških delikata. Niš.

Jovašević, D. (2011). Leksikon krivičnog prava. Beograd.

Jovašević, D. (2014). Krivično pravo, Posebni dio. Beograd.

Jovašević, D. (2016). Krivično pravo, Opšti dio. Beograd.

Jovašević, D., \& Milošević, M. (2001). Criminal legal aspects of accidental provocation of environmnetal hazards by causing general alertness. Beograd: Nauka, bezbjednost, policija, Beograd, (2).

Jovašević, D., \& Milošević, M. (2002). Odgovornost za štetu izazvanu požarom i eksplozijom. Zbornik radova "Sistemska analiza šteta u privredi, osiguranje i preventivno inženjerstvo", Beograd.

Jovašević, D. (2012). Prekršajno pravo. Niš.

Jovašević, D., \& Ikanović, V. (2012). Krivično pravo Republike Srpske, Posebni dio. Banja Luka.

Jugović, L. (1990). Krivičnopravna zaštita čovjekove sredine. Beograd: Bezbjednost i društvena samozaštita, (9).

Kosanović, S. (1995). Krivičnopravna zaštita okoline u jugoslovenskom pravu. Beograd; Pravni život, (9).

Krivokapić, B. (1990). Zaštita od jonizujućeg zračenja — pravno uređenje. Beograd: Bezbjednost i društvena samozaštita, (11).

Ljuština, A. (2005). Pojam i osnovne karakteristike organizovanog ekološkog kriminaliteta. Zbornik radova "Organizovani kriminalitet-stanje i mjere zaštite", Beograd.

Lutenberger, A. (2007). Ekosustavni pristup zaštiti i očuvanju morskog okoliša i okoliša. Zagreb: Poredbeno pomorsko pravo, (46). 
Matijević, M. (1998). Ekologija kroz sudsku praksu—krivičnopravni aspekt. Zagreb: Odvjetnik, (1-2).

Mecanović, I. (1986). Zaštita životne sredine i njen pravni režim. Osijek: Pravni vjesnik, (2).

Milenković, D. (1998). Ekološko pravo i uloga uprave u zaštiti životne sredine. Beograd: Izbor sudske prakse, (4).

Petrović, B., Jovašević, D., \& Ferhatović, A. (2016). Krivično pravo 2. Sarajevo.

Prodanović, Č. (1998). Uloga javnog tužilaštva u zaštiti čovjekove okoline. Zagreb: Odvjetnik, Zagreb, (1-2).

Simović, M. (1988). Krivično zakonodavstvo i zaštita životne sredine. Sarajevo: Pravna misao, (11-12).

Todorović, P., \& Jovašević, D. (2003). Odgovornost za rizik u životnoj sredini u republičkom krivičnom zakonodavstvu. Zbornik radova "Zaštita životne sredine gradova i prigradskih naselja”, Novi Sad.

Vrhovšek, M. (2007). Krivičnopravna zaštita životne sredine prema novom Krivičnom zakoniku Republike Srbije. Beograd: Izbor sudske prakse, (1). 